OPEN ACCESS

Edited by: Bey Hing Goh,

Monash University Malaysia, Malaysia

Reviewed by:

Pinarosa Avato,

Università degli Studi di Bari Aldo

Moro, Italy

Ru Yan,

University of Macau, China

${ }^{*}$ Correspondence:

Yanhua L

liyanhua1970@163.com

${ }^{\dagger}$ These authors have contributed equally to this work.

Specialty section:

This article was submitted to

Ethnopharmacology,

a section of the journal

Frontiers in Pharmacology

Received: 27 February 2017 Accepted: 31 May 2017

Published: 16 June 2017

Citation:

Wang S, Wang C, Gao L, Cai $H_{\text {, }}$

Zhou Y, Yang Y, Xu C, Ding W,

Chen J, Muhammad I, Chen $X$,

He X, Liu D and Li Y (2017) Rutin

Inhibits Streptococcus suis Biofilm

Formation by Affecting CPS

Biosynthesis.

Front. Pharmacol. 8:379

doi: 10.3389/fphar.2017.00379

\title{
Rutin Inhibits Streptococcus suis Biofilm Formation by Affecting CPS Biosynthesis
}

\begin{abstract}
Shuai Wang 1,2t, Chang Wang 1,2t, Lingfei Gao 1,2, Hua Cai ${ }^{3}$, Yonghui Zhou 1,2, Yanbei Yang ${ }^{1,2}$, Changgeng $\mathrm{Xu}^{1,2}$, Wenya Ding ${ }^{1,2}$, Jianqing Chen ${ }^{1,2}$, Ishfaq Muhammad ${ }^{1}$, Xueying Chen ${ }^{1,2}$, Xinmiao He ${ }^{3}$, Di Liü and Yanhua $\mathrm{Li}^{1,2 *}$
\end{abstract}

\begin{abstract}
${ }^{1}$ College of Veterinary Medicine, Northeast Agricultural University, Harbin, China, ${ }^{2}$ Heilongjiang Key Laboratory for Animal Disease Control and Pharmaceutical Development, Harbin, China, ${ }^{3}$ Harbin Pharmaceutical Group Bio-Vaccine Co. Ltd. (Hayao Vaccine), Harbin, China, ${ }^{4}$ Heilongjiang Key Laboratory for Animal Disease Control and Pharmaceutical Development, Northeast Agricultural University, Harbin, China
\end{abstract}

Streptococcus suis (S. suis) form biofilms and causes severe diseases in humans and pigs. Biofilms are communities of microbes embedded in a matrix of extracellular polymeric substances. Eradicating biofilms with the use of antibiotics or biocides is often ineffective and needs replacement with other potential agents. Compared to conventional agents, promising and potential alternatives are biofilm-inhibiting compounds without impairing growth. Here, we screened a S. suis adhesion inhibitor, rutin, derived from Syringa. Rutin, a kind of flavonoids, shows efficient biofilm inhibition of $S$. suis without impairing its growth. Capsular polysaccharides(CPS) are reported to be involved in its adherence to influence bacterial biofilm formation. We investigated the effect of rutin on S. suis CPS content and structure. The results showed that rutin was beneficial to improve the CPS content of $S$. suis without changing its structure. We further provided evidence that rutin specifically affected $S$. suis biofilm susceptibility by affecting CPS biosynthesis in vitro. The study explores the antibiofilm potential of rutin against $S$. suis which can be used as an adhesion inhibitor for the prevention of $S$. suis biofilm-related infections. Nevertheless, rutin could be used as a novel natural inhibitor of biolfilm and its molecular mechanism provide basis for its pharmacological and clinical applications.

Keywords: Streptococcus suis, biofilms, rutin, adhesion, CPS

\section{INTRODUCTION}

Streptococcus suis (S. suis) is a major swine pathogen and a zoonotic agent that causes severe invasive diseases in pigs, including meningitis and streptococcal toxic shock-like syndrome (Gottschalk et al., 2010). What's more, S. suis is a major public health issue and an emerging zoonotic agent in Southeast and East Asia (Sriskandan and Slater, 2006; Gottschalk et al., 2007). In 2005, a survey showed more than two hundred human cases of S. suis in China among them 39 were found dead (Yang et al., 2006). Meanwhile, studies showed that $S$. suis could cause persistent infections due to its ability of forming biofilms in vivo (Wang Y. et al., 2011).

Biofilms are microbial sessile communities characterized by bacterium that are adhered to biotic or abiotic surfaces or to each other, are surrounded by a polymer matrix and exhibit an altered phenotype compared to planktonic cells (Fux et al., 2005). Biofilm cells are known to be 10-1,000 
times more opposed to antimicrobial agents compared to planktonic cells (Gilbert et al., 1997). This may be due to a decreased penetration of antibiotics, a decreased growth rate of the biofilm cells and/or a decreased metabolism of bacterial cells in biofilms (Kiedrowski and Horswill, 2011). In addition, the presence of persisted cells and the expression of specific resistance genes in biofilms may contribute to this tolerance (Conlon, 2014).

Bacterial adhesion to a substrate is the first essential step for biofilm formation. Meanwhile, it has been reported that CPS was involved in the adherence of pneumococci to host cells (Allegrucci and Sauer, 2007), and the encapsulated isolated clinical pneumococcal were found to have impaired biofilm formation (Moscoso et al., 2006). Previously, several studies have demonstrated that the mutant strain of nonencapsulated pneumococcal showed stronger adhesion ability and enhanced biofilm formation ability than their encapsulated parents in vitro (Waite et al., 2001; Moscoso et al., 2006; Allegrucci and Sauer, 2007; McEllistrem et al., 2007). It is well known that $\mathrm{Wzx} / \mathrm{Wzy}$-dependent pathway is responsible for the formation of S. suis CPS (Wang K. et al., 2011). In this pathway, first, an initial monosaccharide is linked to the inner face of the cytoplasmic membrane by an initial sugar transferase. Second, other monosaccharides are joined sequentially by specific glycosyltransferases to assemble repeated units. Then, the repeated units are transported to the outer surface of the cytoplasmic membrane by Wzx flippase, and each repeated unit is combined and polymerized to form the lipid linked CP by Wzy polymerase. Finally, mature CPS is translocated to the peptidoglycan by the membrane protein complex (Okura et al., 2013). The genes involved in this pathway contain a gene cluster (cps gene cluster) and are usually located at the same chromosomal locus (Bentley et al., 2006). The cps gene cluster includes the genes encoding the initial sugar transferase, Wzx flippase $(w z x)$, Wzy polymerase $(w z y)$, additional glycosyltransferases, and enzymes to modify the repeated units or to add other moieties on CPS (Roberts, 1996; Bentley et al., 2006; Okura et al., 2013). Therefore, adhesion inhibitors were screened by affecting CPS biosynthesis.

Recently, few novel bactericidal or bacteriostatic agents have been developed and their antimicrobial activity lead to selective pressure, with antimicrobial resistance as an inevitable consequence of their use (Roca et al., 2015). For this reason, innovative antimicrobials with novel targets and modes of action are needed. A recently developed method aimed at interference with biofilm development without affecting bacterial growth compared to traditional bactericidal or bacteriostatic uses to inhibit biofilms (McDougald et al., 2012). Various natural products are successful in regulating biofilms development. The benefits of using natural products in biofilm inhibition are their higher specificity and lower toxicity compared to synthetic compounds (Koo and Jeon, 2009). For example, mulberry leaves has been shown to inhibit Streptococcus mutans biofilm formation by affecting bacterial adhesion (Islam et al., 2008).

Rutin, a well-known and widely used citrus flavonoid glycoside, has a lot of benefical pharmacological effects such as antimicrobial, antioxidant, anti-inflammatory, and antihypertensive effects (Erlund et al., 2000; Middleton et al.,
2000). It is found in many foods, such as orange, buckwheat, apple, onion, lemon, and grapefruit. In addition, rutin was identified as the principal anti-biofilm compounds in burdock leaf and inhibited biofilm formation of Pseudomonas aeruginosa by betabolomics-based screening (Lou et al., 2015). We have analyzed the relationship between the spectrum and the impact of Syringa oblata Lindl. aqueous extract on S. suis biofilms in vitro. According to high performance liquid chromatography (HPLC) fingerprint and anti-biofilm activity test, gray relational analysis was applied to find the active composition. Rutin make significant contribution to anti-biofilm activity according to the relational grade analysis. Our previous results also showed that rutin was confirmed as the main anti-biofilm compounds in Syringa oblata Lindl. aqueous extract and truly affects S. suis biofilms in vitro (Bai et al., 2017).

In this work, we provided evidence that rutin inhibits the biofilm formation of $S$. suis by affecting CPS biosynthesis in vitro. The study explores the antibiofilm potential of rutin against S. suis which can be used as an adhesion inhibitor for the prevention of S. suis biofilm-related infections.

\section{MATERIALS AND METHODS}

\section{Bacterial Strains and Growth Conditions}

Streptococcus suis (ATCC700794) was purchased from the American Type Culture Collection. Bacteria were cultured aerobically as mentioned in our previous study (Yang et al., 2015). Briefly, bacteria grown at $37^{\circ} \mathrm{C}$ in Todd-Hewitt broth (THB; Sigma-Aldrich) or Todd-Hewitt broth agar (THA) added with $5 \%(\mathrm{v} / \mathrm{v})$ fetal bovine serum (Sijiqing Ltd, Hangzhou, China) (Yang et al., 2015).

\section{Effectiveness of Rutin on Inhibition of Biofilm by the TCP Assay}

The effect of rutin on $S$. suis biofilm formation was assayed as previously described (Bai et al., 2017). Briefly, a mid-exponential growth culture of $S$. suis was diluted to an optical density of $10^{5}-10^{6}$ cells $/ \mathrm{mL}$. Then, $100 \mu \mathrm{L}$ of cultures distributed in 96well microplates (Corning Costar, NY, United States) containing $100 \mu \mathrm{L}$ of sub-MICs of rutin solution $(1 / 2 \mathrm{MIC}(0.1563 \mathrm{mg} / \mathrm{mL})$, $1 / 4 \operatorname{MIC}(0.0781 \mathrm{mg} / \mathrm{mL}), 1 / 8 \mathrm{MIC}(0.0391 \mathrm{mg} / \mathrm{mL})$, and $1 / 16$ MIC $(0.0195 \mathrm{mg} / \mathrm{mL}))$, negative control wells were included. After incubation for $72 \mathrm{~h}$ at $37^{\circ} \mathrm{C}$ without shaking, the wells were washed twice with distilled water, dried and fixed with $200 \mu \mathrm{L}$ of $99 \%$ methanol for $5 \mathrm{~min}$. Then, the wells were decanted, left to dry and stained with $200 \mu \mathrm{L}$ of $2 \%$ crystal violet for another $5 \mathrm{~min}$. Excess stain was rinsed off gently by water, the microplates were air dried, and the bound dye was solubilized with $200 \mu \mathrm{L}$ of $33 \%$ glacial acetic acid. Crystal violet-stained bacteria were quantified measuring the A595 nm (DG5033A, Huadong Ltd, Nanjing, China). The reported values are the means of three measurements (Bai et al., 2017).

\section{Growth Inhibitory Test}

Growth inhibitory test was performed by the previously described method with minor modifications (Yang et al., 
2015). Briefly, the culture medium was added with $1 / 4$ MIC $(0.0781 \mathrm{mg} / \mathrm{mL})$ of rutin and incubated at $37^{\circ} \mathrm{C}$ for $24 \mathrm{~h}$. Control cells were also incubated in the absence of rutin. The rutintreated and untreated cultures samples were taken every hour for measuring at $\mathrm{OD}_{600 \mathrm{~nm}}$.

\section{Observation by Scanning Electron Microscopy (SEM)}

A mid-exponential growth culture of $S$. suis was diluted to an optical density of $10^{5}-10^{6}$ cells $/ \mathrm{mL}$. Then, a volume of $2 \mathrm{~mL}$ was added to a 6-well microplates (Corning Costar, NY, United States) containing a sterilized rough glass slide $(1 \mathrm{~cm} \times 1 \mathrm{~cm})$. After culturing in stationary conditions for $72 \mathrm{~h}$ at $37^{\circ} \mathrm{C}$, the glass slide were rinsed with sterile PBS in order to eliminate any non-adherent bacteria. The remaining biofilms were fixed with fixative solution ( $2 \mathrm{mM} \mathrm{CaCl}_{2}$ in $0.2 \mathrm{M}$ cacodylate buffer, $2.5 \%$ $(\mathrm{w} / \mathrm{v})$ glutaraldehyde, $4 \%(\mathrm{w} / \mathrm{v})$ paraformaldehyde, $\mathrm{pH} 7.2$ ) for $6 \mathrm{~h}$ and washed with PBS, then fixed in $2 \%$ osmium tetroxide containing $6 \%(\mathrm{w} / \mathrm{v})$ sucrose and $2 \mathrm{mM}$ potassium ferrocyanide in cacodylate buffer. The samples were dried, gold sputtered with an ion sputtering instrument (current $15 \mathrm{~mA}, 2 \mathrm{~min}$ ) and observed using SEM (FEI Quanta, Netherland) (Bai et al., 2017).

\section{Adhesion Assays}

Adhesion assays was performed as previously described (Hamada et al., 1981). In brief, a mid-exponential growth culture of S. suis was diluted to an optical density of $10^{5}-10^{6}$ cells $/ \mathrm{mL}$ and each $2 \mathrm{~mL}$ [THB or $1 / 4 \mathrm{MIC}(0.0781 \mathrm{mg} / \mathrm{mL})$ rutin] were added to a 6-well microplate (Corning Costar, NY, United States) containing sterilized rough organic membrane $(1 \mathrm{~cm} \times 1 \mathrm{~cm})$. The plate were incubated in stationary conditions for for $24 \mathrm{~h}$ at $37^{\circ} \mathrm{C}$, the nonadherent bacteria were decanted, and the remaining adherence were removed by $0.5 \mathrm{M}$ of sodium hydroxide. Then, the cells were quantified at $600 \mathrm{~nm}$. Percentage adherence $=\left[\mathrm{OD}_{600}\right.$ of adhered cells/ ( $\mathrm{OD}_{600}$ of adhered cells $+\mathrm{OD}_{600}$ of supernatant cells)].

\section{PCR Amplification and Nucleotide Sequencing}

To investigate whether rutin cause the cps gene mutation, a mid-exponential growth culture of $S$. suis was diluted to an optical density of $10^{5}-10^{6}$ cells $/ \mathrm{mL}$ and the culture medium was supplemented with $1 / 4 \mathrm{MIC}(0.0781 \mathrm{mg} / \mathrm{mL})$ of rutin incubating at $37^{\circ} \mathrm{C}$ for $24 \mathrm{~h}$. Control cells were also incubated in the absence of rutin. Chromosomal DNA from $S$. suis was prepared as previously described (Qin et al., 2006). Briefly, Bacterial colonies were suspended in $50 \mu \mathrm{L}$ distilled water to extract DNA, followed by boiling for $5 \mathrm{~min}$. Ex Taq DNA polymerase was used to perform PCR choosing the conditions: $94^{\circ} \mathrm{C}$ for $10 \mathrm{~min}, 35$ cycles of $94^{\circ} \mathrm{C}$ for $30 \mathrm{~s}, 57^{\circ} \mathrm{C}-60^{\circ} \mathrm{C}$ for $30 \mathrm{~s}$ (Details are shown in Table 1), and $72^{\circ} \mathrm{C}$ for $30 \mathrm{~s}$; followed by a final extension step at $72^{\circ} \mathrm{C}$ for $10 \mathrm{~min}$. The following primer pairs used in this work are listed in Table 1. The identity of the PCR product was confirmed by DNA sequencing. Sequence alignments were conducted using the BLAST program.

\section{RNA Isolation and Quantitative RT-PCR}

The quantitative Real-Time PCR was performed as described in our previous study (Yang et al., 2015). To investigate the effect of rutin on expression of cps gene, a mid-exponential growth culture of $S$. suis was diluted to an optical density of $10^{5}-10^{6}$ cells $/ \mathrm{mL}$ and the culture medium was added with $1 / 4$ MIC $(0.0781 \mathrm{mg} / \mathrm{mL})$ of rutin prior to further incubating at $37^{\circ} \mathrm{C}$ for $24 \mathrm{~h}$. The control cells were also incubated without rutin. Bacteria were collected by centrifugation $(12,000 \times g, 5 \mathrm{~min}$,

TABLE 1 | Primers used for the PCR.

\begin{tabular}{|c|c|c|}
\hline Genes & Primer sequence & $\begin{array}{l}\text { Annealing } \\
\text { temperature }\end{array}$ \\
\hline \multirow[t]{2}{*}{$\operatorname{cps} 2 A$} & Forward: 5'- TTCCACCCACCAAGTCGA -3' & $60^{\circ} \mathrm{C}$ \\
\hline & Reverse: 5' - TGGCGGGCAAAATCAATA -3' & \\
\hline \multirow[t]{2}{*}{$\operatorname{cps} 2 B$} & Forward: 5' - TCTATTTCTGTGCGTGAT -3' & $60^{\circ} \mathrm{C}$ \\
\hline & Reverse: 5' - TTGGAGTGGTTGGTTCTT -3' & \\
\hline \multirow[t]{2}{*}{$\operatorname{cps} 2 \mathrm{C}$} & Forward: 5' - ATAACCTGAACGAGCATA -3' & $57^{\circ} \mathrm{C}$ \\
\hline & Reverse: 5' - AGAGAGGGAGTAAATAAAAC -3' & \\
\hline \multirow[t]{2}{*}{$\operatorname{cps} 2 D$} & Forward: 5' - GATIIITCTGGTGTTC -3' & $60^{\circ} \mathrm{C}$ \\
\hline & Reverse: 5' - TCATATTTGGTGTGGATG -3' & \\
\hline \multirow[t]{2}{*}{$\operatorname{cps} 2 E$} & Forward: 5'- TGTCCATTITGAACATCC -3' & $60^{\circ} \mathrm{C}$ \\
\hline & Reverse: 5' - TाTGCTCAGAAACGAGT -3' & \\
\hline \multirow[t]{2}{*}{$\operatorname{cps} 2 F$} & Forward: 5' - AGGACCAATCCGACAAGC -3' & $60^{\circ} \mathrm{C}$ \\
\hline & Reverse: 5' - TGAACATAATGGAGCAAC -3' & \\
\hline \multirow[t]{2}{*}{$\operatorname{cps} 2 G$} & Forward: 5' - CATACCAATGACAAGAGC -3' & $60^{\circ} \mathrm{C}$ \\
\hline & Reverse: 5' - GACCAAATCAGTGTAATCTA -3' & \\
\hline \multirow[t]{2}{*}{$\operatorname{cps} 2 \mathrm{H}$} & Forward: 5'- GCCTCTTATTCAGGTTAT -3' & $60^{\circ} \mathrm{C}$ \\
\hline & Reverse: 5'- CTITCTIITGTITCG -3' & \\
\hline \multirow[t]{2}{*}{ cps2l } & Forward: 5' - GTACTCCATTGTCTITGT -3' & $57^{\circ} \mathrm{C}$ \\
\hline & Reverse: 5' - GAATTGTIITGATTCTT -3' & \\
\hline \multirow[t]{2}{*}{ cps 2J } & Forward: 5' - ACCGCTCATATAATGATT -3' & $57^{\circ} \mathrm{C}$ \\
\hline & Reverse: 5' - GGAGGGTTACTTGCTACT -3' & \\
\hline \multirow[t]{2}{*}{$\operatorname{cps} 2 \mathrm{~K}$} & Forward: 5' - CCAGCAACTGCCACAAGG -3' & $57^{\circ} \mathrm{C}$ \\
\hline & Reverse: 5'- GCATAAGTCGCGCCAAGG -3' & \\
\hline \multirow[t]{2}{*}{$\operatorname{cps} 2 L$} & Forward: 5' - CAGAAAGCAACAGAAAAA -3' & $60^{\circ} \mathrm{C}$ \\
\hline & Reverse: $5^{\prime}$ - GAATCCAACAAATAGTAGAATA - -3' & \\
\hline \multirow[t]{2}{*}{$\operatorname{cps} 2 \mathrm{M}$} & Forward: 5' - AACAGGCAAATTAGAAAG -3' & $60^{\circ} \mathrm{C}$ \\
\hline & Reverse: $5^{\prime}$ - TGATAAAGTATGGACAGAAG -3' & \\
\hline \multirow[t]{2}{*}{$\operatorname{cps} 2 \mathrm{~N}$} & Forward: 5' - CTCGTGGGTGCGGTTITA -3' & $60^{\circ} \mathrm{C}$ \\
\hline & Reverse: 5' - CAGCCCTTGTCTTGGGATTA -3' & \\
\hline \multirow[t]{2}{*}{ cps 20} & Forward: 5' - CGATAGGGGCTGACTGAG -3' & $57^{\circ} \mathrm{C}$ \\
\hline & Reverse: 5' - CGCGAGAAATTTGATGA -3' & \\
\hline \multirow[t]{2}{*}{$\operatorname{cps} 2 P$} & Forward: 5' - AAGCAGGGTAAGGGGTTG -3' & $60^{\circ} \mathrm{C}$ \\
\hline & Reverse: 5' - ACTGGTATGGCTGTTATGGA -3' & \\
\hline \multirow[t]{2}{*}{$\operatorname{cps} 2 Q$} & Forward: 5' - CCGCTTCGATGTCTTTGA -3' & $60^{\circ} \mathrm{C}$ \\
\hline & Reverse: 5' - TGGGATTATGCGTCGCTTAT -3' & \\
\hline \multirow[t]{2}{*}{$\operatorname{cps} 2 R$} & Forward: 5' - TATAGTGACGAAGACAGC -3' & $60^{\circ} \mathrm{C}$ \\
\hline & Reverse: $5^{\prime}$-ATATITTGAAGATAAACCG -3' & \\
\hline \multirow[t]{2}{*}{$\operatorname{cps} 2 S$} & Forward: 5'-AACAAGGCTAACAGACGA -3' & $60^{\circ} \mathrm{C}$ \\
\hline & Reverse: 5'-GTGATGACGAAGGAAGAT -3' & \\
\hline \multirow[t]{2}{*}{$\operatorname{cps} 2 T$} & Forward: 5'-GCAACTAAAAATAAATTG -3' & $57^{\circ} \mathrm{C}$ \\
\hline & Reverse: 5'-AAGAGTGCTCTAAGACCA -3' & \\
\hline \multirow[t]{2}{*}{$\operatorname{cps} 2 U$} & Forward: 5'-ATACCTCGCCATCTITA -3' & $60^{\circ} \mathrm{C}$ \\
\hline & Reverse: 5'-GCTGATTCCCTCTIITTG -3' & \\
\hline
\end{tabular}


$4^{\circ} \mathrm{C}$ ) and treated with an RNASE REMOVER I (Huayueyang Ltd, Beijing, China). RNA extraction was performed with an E.Z.N.A. Bacterial RNA isolating kit (Omega, Beijing, China) following the manufacturer's instructions. RNA (100 ng/mL) was reverse transcribed in S1000 thermal cycler (Bio-Rad Laboratories) by using Moloney murine leukemia virus reverse transcriptase and random hexamers. The specific primers used for the quantitative RT-PCR (listed in Table 2) were designed by Takara Company (Takara Ltd, Dalian, Liaoning, China). The 16S rRNA gene was used for normalization of target genes. The amplification conditions for cps and 16S rRNA were $94^{\circ} \mathrm{C}$ for $10 \mathrm{~min}$ followed by 30 cycles at $94^{\circ} \mathrm{C}$ for $15 \mathrm{~s}, 60^{\circ} \mathrm{C}$ for $60 \mathrm{~s}$ and $72^{\circ} \mathrm{C}$ for $20 \mathrm{~s}$, and then $72^{\circ} \mathrm{C}$ for $10 \mathrm{~min}$ (Yang et al., 2015).

TABLE 2 | Primers used for the quantitative RT-PCR analysis.

\begin{tabular}{|c|c|}
\hline Genes & Primer sequence \\
\hline \multirow[t]{2}{*}{$\operatorname{cps} 2 A$} & Forward: 5'-ATGAAAAAGAGAAGCGGACGAAGTA-3 \\
\hline & Reverse: 5'- TTATIITCAACAAGTACGGACTGA-3' \\
\hline \multirow[t]{2}{*}{$\operatorname{cps} 2 B$} & Forward: 5'-ATGAACAATCAAGAAGTAAATGCAA-3' \\
\hline & Reverse: 5'- CTATITAATTTCTTCGAATCTGGT-3' \\
\hline \multirow[t]{2}{*}{$\operatorname{cps} 2 \mathrm{C}$} & Forward: 5'-ATGGCGATGTTAGAAATTGCACGTA-3' \\
\hline & Reverse: 5'- TTAGGCTIIITGCCGTAATTCCG-3' \\
\hline \multirow[t]{2}{*}{$\operatorname{cps} 2 D$} & Forward: 5'-ATGATTGATATCCATTCGCATATCA-3' \\
\hline & Reverse: 5'- TTACTGTACTTGATIITCAATATC-3' \\
\hline \multirow[t]{2}{*}{$\operatorname{cps} 2 E$} & Forward: 5'-ATGAATATTGAAATAGGATATCGCC-3' \\
\hline & 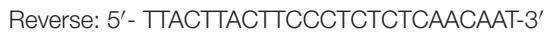 \\
\hline \multirow[t]{2}{*}{$\operatorname{cps} 2 F$} & Forward: 5'-ATGAGAACAGTTTATATTATTGGTT-3' \\
\hline & Reverse: $5^{\prime}$ - TТATCCTTTAAACAACTTCTCATAC-3' \\
\hline \multirow[t]{2}{*}{$\operatorname{cps} 2 G$} & Forward: 5'-ATGAAAAAGATTCTATATCTCCATG-3' \\
\hline & Reverse: 5' - TCAGTATACTTTGAGGGAGGTGTAG-3' \\
\hline \multirow[t]{2}{*}{$\operatorname{cps} 2 \mathrm{~J}$} & Forward: 5'-ATGGAAAAAGTCAGCATTATTGTAC-3' \\
\hline & 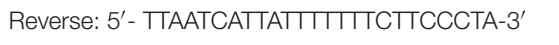 \\
\hline \multirow[t]{2}{*}{$\operatorname{cps} 2 \mathrm{~K}$} & Forward: 5'-ATGATTAACATTTCTATCATCGTCC-3' \\
\hline & Reverse: 5'- TTACCGAGTACTACTTCACTTCTT-3' \\
\hline \multirow[t]{2}{*}{$\operatorname{cps} 2 L$} & Forward: 5'-ATGAATCCAACAAATAGTAGAATAG-3' \\
\hline & Reverse: 5' - TCAGATGGTTCTCGAATAGCTCAAT-3' \\
\hline \multirow[t]{2}{*}{$\operatorname{cps} 2 \mathrm{M}$} & Forward: 5'-GTGCGTTCCAAGGTAGATACTITCA-3' \\
\hline & Reverse: 5' - TTATCGTITTCCACGTACTCTCATA-3' \\
\hline \multirow[t]{2}{*}{$\operatorname{cps} 2 \mathrm{~N}$} & Forward: 5'-TTGAGACGAATTTATATTTGCCATA-3' \\
\hline & Reverse: $5^{\prime}$ - CTATTCTATCCCCTCACGCAAAATA-3' \\
\hline \multirow[t]{2}{*}{$\operatorname{cps} 2 P$} & Forward: 5'-ATGGTTTATATTATTGCAGAAATTG-3' \\
\hline & Reverse: 5'- TTACATTTGATTITCAAAAGCACTA-3' \\
\hline \multirow[t]{2}{*}{$\operatorname{cps} 2 \mathrm{Q}$} & Forward: 5'-ATGAAAAAAATTTGTाTGTGACAG-3' \\
\hline & Reverse: 5'- CTATCTATCATAAAACTCTTTCATG-3' \\
\hline \multirow[t]{2}{*}{$\operatorname{cps} 2 R$} & Forward: 5'-ATGAAAAAAGTAGCCTTCTAGGAG-3' \\
\hline & Reverse: 5'- CTATTTAATCTITCTAGCAGGTACA-3' \\
\hline \multirow[t]{2}{*}{$\operatorname{cps} 2 S$} & Forward: 5'-ATGGAACCAATTTGTCTGATTCCTG-3' \\
\hline & Reverse: 5'- TTATCTTGTCAAACTTGTCAAAATC-3' \\
\hline \multirow[t]{2}{*}{$\operatorname{cps} 2 T$} & Forward: 5'-ATGAAGCAATTGCTACAGTATTATT-3' \\
\hline & Reverse: 5'- CTAATAGTATITTAATATATACTCC-3' \\
\hline \multirow[t]{2}{*}{$\operatorname{cps} 2 U$} & Forward: 5'-TTGTTAGTTATAATTTGGCTAGAG-3' \\
\hline & Reverse: 5' - TTAAAAAAGGGACTTCAACTTCAAT-3' \\
\hline \multirow[t]{2}{*}{$\operatorname{cps} 2 \mathrm{~V}$} & Forward: 5'-TTATAATGCACTAGTATACTGTATA-3' \\
\hline & Reverse: 5'- ATGTCTCATTGGAATCAATIITTAA-3' \\
\hline \multirow[t]{2}{*}{$16 S$ rRNA } & Forward: 5'- TGCTAGTCACCGTAAGGCTAAG -3' \\
\hline & Reverse: 5' - GGCTGCAAGATTTCCTTGAT -3' \\
\hline
\end{tabular}

\section{Capsule Extraction, and Capsular Polysaccharide Purification and Isolation}

Bacteria were grown in $50 \mathrm{~mL}$ of Todd Hewitt broth (THB) at $37^{\circ} \mathrm{C}$ for $24 \mathrm{~h}$, diluted to $5 \mathrm{~L}$ in fresh $\mathrm{THB}$ with $1 / 4$ MIC $(0.0781 \mathrm{mg} / \mathrm{mL})$ rutin, and cultured for $24 \mathrm{~h}$. Control cells were incubated without rutin. The cells were pelleted by centrifugation at $10000 \mathrm{~g}$, suspended in $0.1 \mathrm{~mol} / \mathrm{L}^{-1}$ Glycinebuffer (Biotopped Ltd, Beijing, China) solution pH 9.2. The CPS was prepared as previously described (Katsumi et al., 1996), with some modifications. Briefly, nucleic acids were removed by precipitation by adding $0.1 \mathrm{~mol} / \mathrm{L}^{-1} \mathrm{CaCl}_{2}$ (Tianli Ltd, Tianjin, China) and ethanol (Tianli Ltd, Tianjin, China) to $25 \% \mathrm{v} / \mathrm{v}$, and then centrifuged at $7000 \mathrm{~g}$ at $25^{\circ} \mathrm{C}$. The ethanol concentration in the supernatant was enhanced to $80 \% \mathrm{v} / \mathrm{v}$ to precipitate the CPS. The suspension was centrifuged (9000 $g$ at $4^{\circ} \mathrm{C}$ ) after overnight at $4{ }^{\circ} \mathrm{C}$. The CPS was purified by gel filtration chromatography on a column filled with Sephacryl S-300 (GE Healthcare, Uppsala, Sweden). The elusion was performed with $50 \mathrm{mmol} / \mathrm{L}^{-1} \mathrm{NH}_{4} \mathrm{HCO}_{3}$ (Zhiyuan Ltd, Tianjin, China) at a flow rate of $1.3 \mathrm{~mL} / \mathrm{min}^{-1}$. Purification was collected and freeze dried. The polysaccharides content was determined by the method (using phenol sulfuric acid) described previously (Dubois et al., 1951).

\section{The Desialylated Polysaccharide Production}

Thirty microgram of sample was hydrolyzed with $0.1 \mathrm{~mol} / \mathrm{L}^{-1}$ trifluoroacetic acid to determine the composition of monosaccharide (TFA; Zhiyuan Ltd, Tianjin, China) $(5 \mathrm{~mL})$ at $80^{\circ} \mathrm{C}$ for $60 \mathrm{~min}$, and then centrifuged at $10000 \mathrm{~g}$ for $5 \mathrm{~min}$ using ultrafiltration centrifuge tube (Millipore, Billerica, MA, United States). The centrifugation step was repeated three times, and the samples were collected. The top samples are the desialylated polysaccharide, and the bottom samples are the sialic acid. The solution was evaporated to dryness with a stream of $\mathrm{N}_{2}$ at room temperature. The precipitation was collected, respectively.

\section{PMP-HPLC Analysis}

Alternatively, in order to determine the composition of monosaccharide, $1 \mathrm{mg}$ of sample was hydrolyzed with $2 \mathrm{~mol} / \mathrm{L}^{-1}$ trifluoroacetic acid (TFA) $(0.5 \mathrm{~mL})$ at $120^{\circ} \mathrm{C}$ for $100 \mathrm{~min}$, at $120^{\circ} \mathrm{C}$ for $100 \mathrm{~min}$, followed by evaporation with $\mathrm{N}_{2}$. Polysaccharide hydrolyzate and monosaccharide standard [glucose (Glc), $N$-acetylglucosamine $(\mathrm{GlcN})$, galactose (Gal), rhamnose (Rha)] (Jinshui Ltd, Shanghai, China) by pre-column derivatization with 1-phenyl-3-methyl-5-pyrazolone (PMP; Sigma, St. Louis, MO, United States). The hydrolysates were fully converted to its PMP derivatives according to the previous method (Guitang et al., 2007), with few modifications. Briefly, the sample was dissolved in $100 \mu \mathrm{L}$ of $\mathrm{H}_{2} \mathrm{O}$, and mixed with $100 \mu \mathrm{L}$ of $0.3 \mathrm{~mol} / \mathrm{L} \mathrm{NaOH}$ (Tianli Ltd, Tianjin, China) and $120 \mu \mathrm{L}$ of $0.5 \mathrm{~mol} / \mathrm{L}$ PMP. The mixture was allowed to react for $30 \mathrm{~min}$ at $70^{\circ} \mathrm{C}$. Then, $100 \mu \mathrm{L}$ of $\mathrm{HCl}(0.3 \mathrm{~mol} / \mathrm{L})$ (Ligong Ltd, Harbin, Heilongjiang, China) was added to the mixture and $500 \mu \mathrm{L}$ of chloroform (Ligong Ltd, Harbin, Heilongjiang, China) was added to extract the remaining PMP. The extraction process was repeated three 
times. The PMP derivatized sample solution was filtrated through a $0.22 \mu \mathrm{m}$ membrane. Then the compositions of monosaccharide were determined by HPLC (Waters, Shanghai, China) with an UV detector at $245.0 \mathrm{~nm}$ on a Waters chromatograph. The mobile phase was made of Methanol (Kemiou Ltd, Tianjin, China) (A) and $0.01 \mathrm{~mol} / \mathrm{mL}$ formic acid (Kemiou Ltd, Tianjin, China) $(\mathrm{pH}$ 6.8) (B) $(\mathrm{A}: \mathrm{B}=82: 18, \mathrm{v} / \mathrm{v})$. With $20 \mu \mathrm{L}$ of injection volume, separation was performed on a Spherisorb-C18 Column (Waters, Shanghai, China) $(5 \mu \mathrm{m}, 250 \mathrm{~mm} \times 4.6 \mathrm{~mm})$ at $30^{\circ} \mathrm{C}$ and $1 \mathrm{~mL} / \mathrm{min}$ of flow rate.

\section{Analysis of Sialic Acid by the Fluorometric HPLC Methods}

The sialic acid samples and $N$-acetylgucosamine acid (Neu5Ac; Sigma, St. Louis, MO, United States) were added $0.2 \mathrm{~mL}$ of $0.01 \mathrm{~mol} / \mathrm{L}^{-1} \mathrm{TFA}$ and $0.2 \mathrm{~mL}$ of $7 \mathrm{mmol} / \mathrm{L}^{-1} \mathrm{DMB}$ (TCI, Tokyo, Japan) solution in $5 \mathrm{mmol} / \mathrm{L}$ trifluoroacetic acid containing $1 \mathrm{~mol} / \mathrm{L} 2$-mercaptoethanol and $18 \mathrm{mmol} / \mathrm{L}$ sodium hydrosulfite (Guangfu, Tianjin, China), and incubated at $60^{\circ} \mathrm{C}$ for $2 \mathrm{~h}$. The sample solution filtrated through a $0.22 \mu \mathrm{m}$ membrane after derivatized by DMB. The composition of monosaccharide was determined by HPLC equipped with an EV detector (Ex $373 \mathrm{~nm}$ and Em 448nm) on a Waters chromatographic system. The mobile phase was made of $\mathrm{CH}_{3} \mathrm{OH}(\mathrm{A}), \mathrm{CH}_{3} \mathrm{CN}$ (Kemiou Ltd, Tianjin, China) (B) and 0.05\% TFA (C) (A: B: C = 6:4:90, v/v/v). Separation was performed on a Spherisorb-C18 Column $(5 \mu \mathrm{m}$, $250 \mathrm{~mm} \times 4.6 \mathrm{~mm})$ at $26^{\circ} \mathrm{C}$ and $1 \mathrm{~mL} / \mathrm{min}$ of flow rate at an injection volume of $20 \mu \mathrm{L}$.

\section{Nuclear Magnetic Resonance}

The polysaccharide and the desialylated polysaccharide were exchanged in $33 \mathrm{mmol} / \mathrm{L}^{-1}$ phosphate buffer $\left(\mathrm{pH}\right.$ 8.0) in ${ }^{2} \mathrm{H}_{2} \mathrm{O}$ (99.9 atom $\%{ }^{2} \mathrm{H}$ ), freeze dried, and dissolved in the same amount of ${ }^{2} \mathrm{H}_{2} \mathrm{O}\left(99.96\right.$ atom $\left.\%{ }^{2} \mathrm{H}\right)$. Nuclear magnetic resonance (Bruker, Beijing, China, NMR) spectra were acquired on polysaccharide samples at concentrations of circa $(1 \%-3 \%)$.

\section{Statistical Analysis}

All the assays were performed in triplicate, and the results were expressed as means \pm standard deviations. Data were analyzed by the Student's $t$-test. Statistics were determined using SPSS software, version 18.0.

\section{RESULTS}

\section{Effectiveness of Rutin on Inhibition of Biofilm Formation by the TCP Assay}

We determined the effect of sub-inhibitory concentrations of rutin on biofilm production in vitro. The MIC values of rutin for S. suis was $0.3125 \mu \mathrm{g} \cdot \mathrm{mL}^{-1}$. As shown in Figure 1, 1/2 MIC $(0.1563 \mathrm{mg} / \mathrm{mL})$ and $1 / 4 \mathrm{MIC}(0.0781 \mathrm{mg} / \mathrm{mL})$ of rutin were able to significantly inhibit biofilm production $(p<0.05)$. Rutin at $1 / 8 \mathrm{MIC}(0.0391 \mathrm{mg} / \mathrm{mL})$ and 1/16 MIC $(0.0195 \mathrm{mg} / \mathrm{mL})$ had no significant effect on $S$. suis biofilm formation.
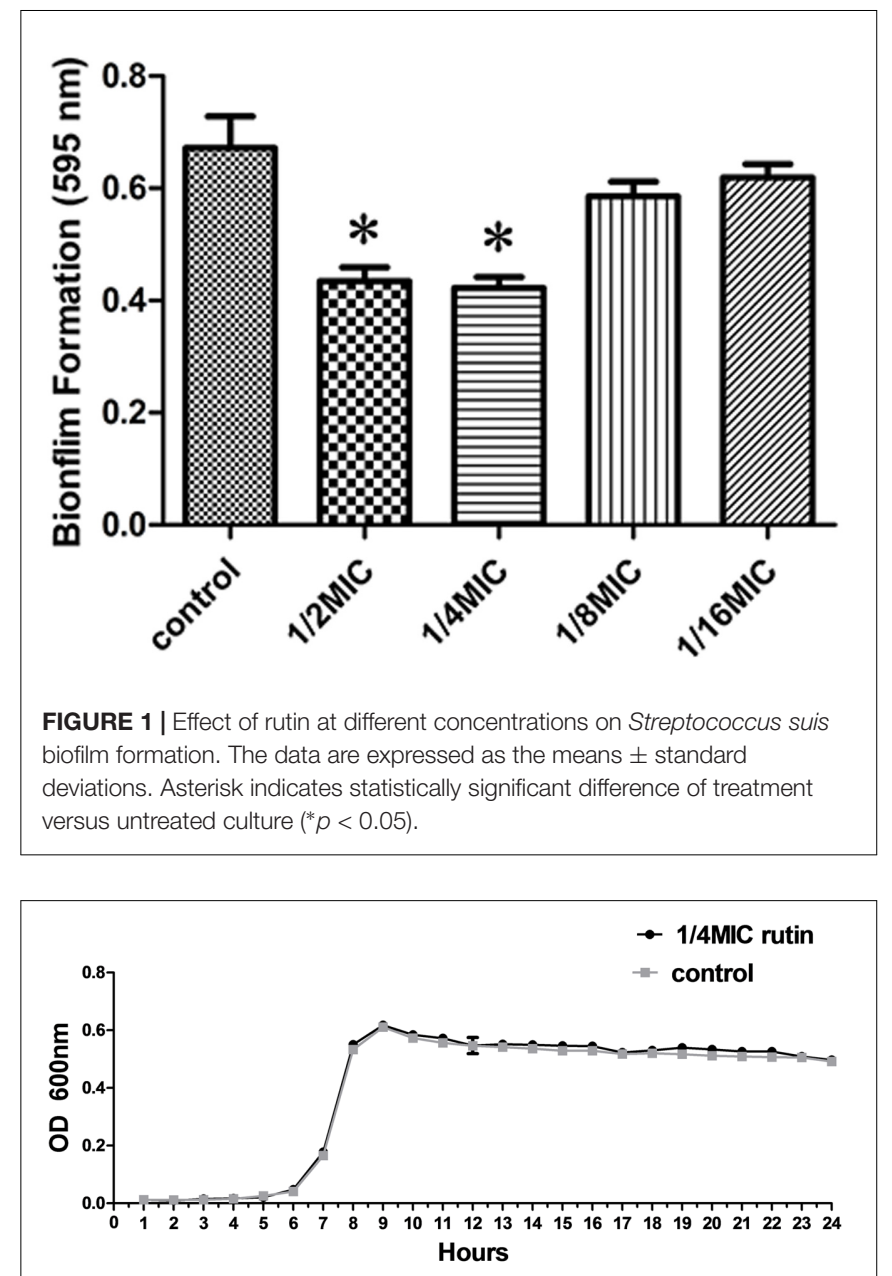

FIGURE 2 | Growth curve of $S$. suis in the absence of rutin and in the presence of rutin at $1 / 4 \mathrm{MIC}(0.0781 \mathrm{mg} / \mathrm{ml})$. The data are expressed as the mean \pm standard deviations.

\section{Growth Inhibitory Activity of Rutin}

The growth of S. suis was measured for cultures with $0 \mathrm{MIC}$ and $1 / 4$ MIC $(0.0781 \mathrm{mg} / \mathrm{mL})$ of rutin. The growth curves for $1 / 4$ MIC of rutin were not significantly different in lag, exponential, and stationary phases during $24 \mathrm{~h}$ of incubation (Figure 2). The results suggested that the growth of $S$. suis was unaffected by the addition of $1 / 4 \mathrm{MIC}(0.0781 \mathrm{mg} / \mathrm{mL})$ rutin.

\section{Direct Observation of Biofilm Formation In Vitro by SEM}

To observe the effect of rutin on biofilm production, the architecture of biofilms formed in the absence or in the presence 1/4 MIC $(0.0781 \mathrm{mg} / \mathrm{mL})$ of rutin was studied by SEM. As shown in Figure 3A, when biofilm was formed in the absence of rutin, the aggregates and microcolonies of S. suis covered almost entirely the glass slide surface. However, when biofilm was formed in the presence $1 / 4 \mathrm{MIC}(0.0781 \mathrm{mg} / \mathrm{mL})$ of rutin, a marked variability in the three-dimensional biofilm architecture was noted. Biofilm thickness is thin and bacteria are scattered 

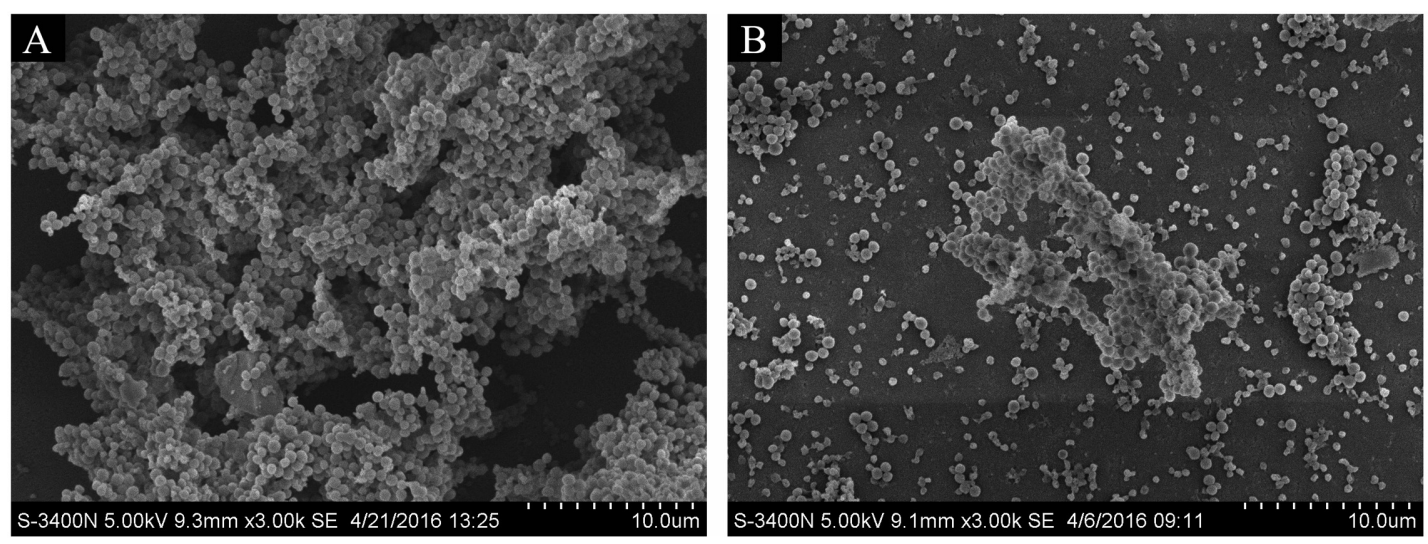

FIGURE 3 | Effect of rutin on S. suis biofilm by scanning electron microscope. Biofilm formation of S. suis without rutin (A). Biofilm formation of S. suis with 1/4 MIC $(0.0781 \mathrm{mg} / \mathrm{ml})$ rutin treatment $(\mathbf{B})$.
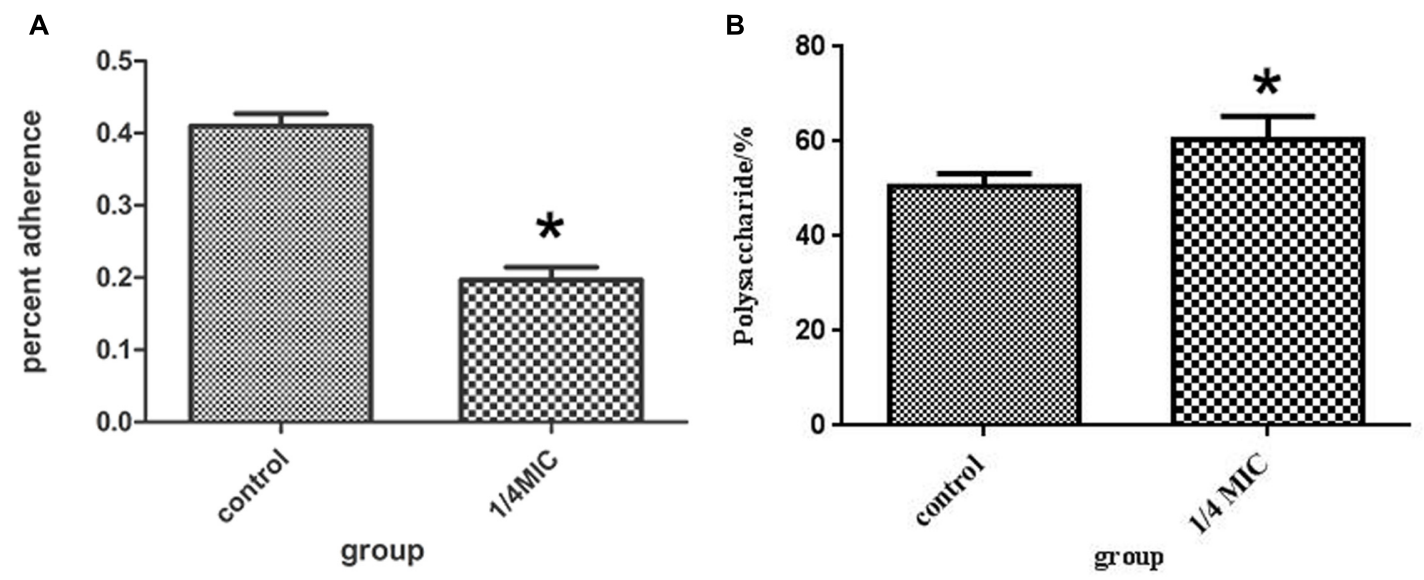

FIGURE 4 | Effect of $1 / 4 \mathrm{MIC}(0.0781 \mathrm{mg} / \mathrm{ml})$ rutin on S. suis adhesion (A). Effect of $1 / 4 \mathrm{MIC}(0.0781 \mathrm{mg} / \mathrm{ml})$ rutin on the polysaccharides content of S. suis (B). The data are expressed as means \pm standard deviations. Asterisk indicates statistically significant difference of treatment versus untreated culture $\left.{ }^{*} p<0.05\right)$.

(Figure 3B). These results suggested that rutin at $1 / 4 \mathrm{MIC}$ $(0.0781 \mathrm{mg} / \mathrm{mL})$ significantly inhibited the biofilm formation of S. suis in vitro.

\section{Anti-adherence Activity of Extract Against S. suis}

The inhibitory effects at $1 / 4 \mathrm{MIC}(0.0781 \mathrm{mg} / \mathrm{mL})$ of rutin on adherence of $S$. suis are shown in Figure 4A. The rutin inhibited adherence in a pronounced manner. The anti-adherence rate of S. suis is $20 \%$ at a concentration of $1 / 4 \mathrm{MIC}(0.0781 \mathrm{mg} / \mathrm{mL})$ of rutin.

\section{PCR Amplification and Nucleotide Sequencing}

The mapping of the cps genes in the genome of S. suis by PCR are shown in Figure 5. Sequencing was performed to confirm that no mutation occurred. Detailed information is shown in the Supplementary Figures S1-S21. The Supplementary Figures
S1-S21 shows the results of cps $2 A-c p s 2 U$ sequence alignment. The sequence of the cps gene cluster has no difference between rutin-treated and untreated cells.

\section{The Effect of 1/4 MIC of Rutin on Expression of cps Genes}

Thereafter, the effect of rutin on the expression profile of $c p s$ gene cluster was analyzed. As displayed in Figure 6, when the culture medium was in the presence $1 / 4 \mathrm{MIC}(0.0781 \mathrm{mg} / \mathrm{mL})$ of rutin, expression of the genes cps $2 C, c p s 2 D, c p s 2 E, c p s 2 J, c p s 2 L, c p s 2 R$, and $c p s 2 Q$ was up regulated. However, the expression of the genes $\operatorname{cps} 2 B, \operatorname{cps} 2 M, \operatorname{cps} 2 K, \operatorname{cps} 2 U$, and $c p s 2 V$ was down regulated.

\section{Capsule Polysaccharide Content Determination}

The rutin effect for polysaccharides content of $S$. suis was shown in Figure 4B. The contents of total sugar were analyzed by phenol-sulfuric method. $50.54 \pm 2.69 \%$ and $60.46 \pm 4.91 \%$ of 


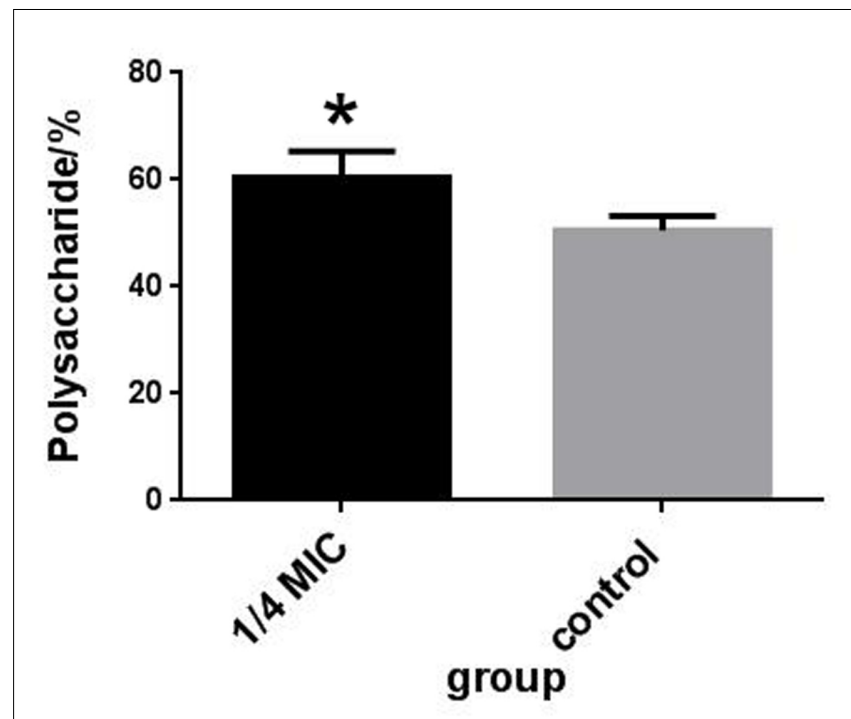

FIGURE 5 | Mapping of the cps in the genome of $S$. suis by PCR. The 1-21 stands for $c p s 2 A-2 U$, respectively.

the polysaccharides content were observed in the control and rutin group, respectively $(P<0.05)$. The results suggested that the polysaccharides content significantly increased when the bacteria was incubated with rutin.

\section{HPLC Characterization of \\ Polysaccharides}

To further clarify polysaccharides, the compositions were examined by acid hydrolysis and HPLC. After PMP derivatization, the composition of monosaccharides from the hydrolyzed products was examined by HPLC. From the chromatograms, Glc and Gla, GlcN and Rha were detected in both rutin group and control group. As shown in Figure 7, the results showed that there was the no significant difference between the rutin and control group.
The molar ratio of monosaccharides (Rha: Gal: Glc: GlcN) was 1:2.22:0.95:0.76 and 1: 2.03: 1.29: 0.74 for the rutin group and control group, respectively. These results exhibited that the monosaccharide compositions had no significant difference when the culture medium was added with $1 / 4 \mathrm{MIC}(0.0781 \mathrm{mg} / \mathrm{mL})$ rutin.

The most significant feature of the sialic acid is their instability. DMB possess significant advantages in its specific reactivity with the $\alpha$-keto acids of sialic acids. After DMB derivatization, the sialic acid from the hydrolyzed products was determined by HPLC. As shown in Figure 8, Neu5Ac was detected in the product of the rutin group and the control group. The ratio of sialic acid content of the control and rutin group was 1:1.84. The results of HPLC suggested that the content of Rha, Glc, Gal, GlcN, and Neu5Ac of rutin group was generally higher than that of control group.

\section{Nuclear Magnetic Resonance}

The ${ }^{1} \mathrm{H}$ NMR spectra of the $S$. suis CPS of rutin group and control group before and after desialylated are shown in Figures 9, 10. The same spectra was observed in the ${ }^{1} \mathrm{H}$ NMR spectra of the S. suis CPS after and before acid hydrolysis reported by the Van Calsteren (Van Calsteren et al., 2010). The ${ }^{1} \mathrm{H}$ NMR spectra of the polysaccharides of $S$. suis of control group and rutin group are shown in Figure 9. There was conformity between two polysaccharides for their ${ }^{1} \mathrm{H}$ NMR spectra. The ${ }^{1} \mathrm{H}$ NMR spectra of the desialylated polysaccharides of $S$. suis control group and rutin treated group are shown in Figure 10. The result showed that there was no difference between the structures of two desialylated polysaccharide. On the ${ }^{1} \mathrm{H}$ NMR spectra, polysaccharide signals were concentrated in the $\delta 3.3 \sim 4.0 \mathrm{ppm}$ range. Reporter resonance signals were identified on both spectra: acetyl methyl protons of $N$-acetylglucosamine near $\delta 2.0$, and methyl protons in position 6 of rhamnose at crica $\delta$ 1.2. Signals characteristic of sialic acid, that is, acetyl methyl protons near $\delta 2.0$ and methylene protons in position 3 at $\delta 2.579$ and 1.591 vanished fully after hydrolysis. The only difference between the spectra of the Figures 9, 10 was the loss of the sialic acid signals.
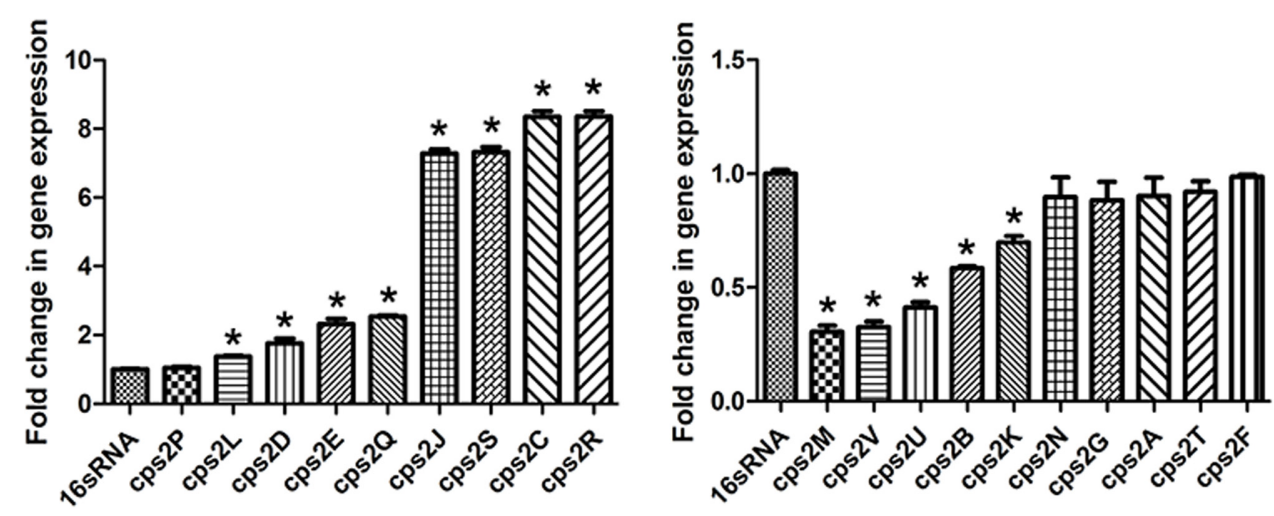

FIGURE 6 | Effect of rutin on mRNA expression of cps genes in S. suis. The data are expressed as means \pm standard deviations. The expression was normalized to $16 \mathrm{~S}$ rRNA. Controls refer to the absence of rutin. Asterisk indicates statistically significant difference of treatment versus untreated culture $\left({ }^{*} p<0.05\right)$. 

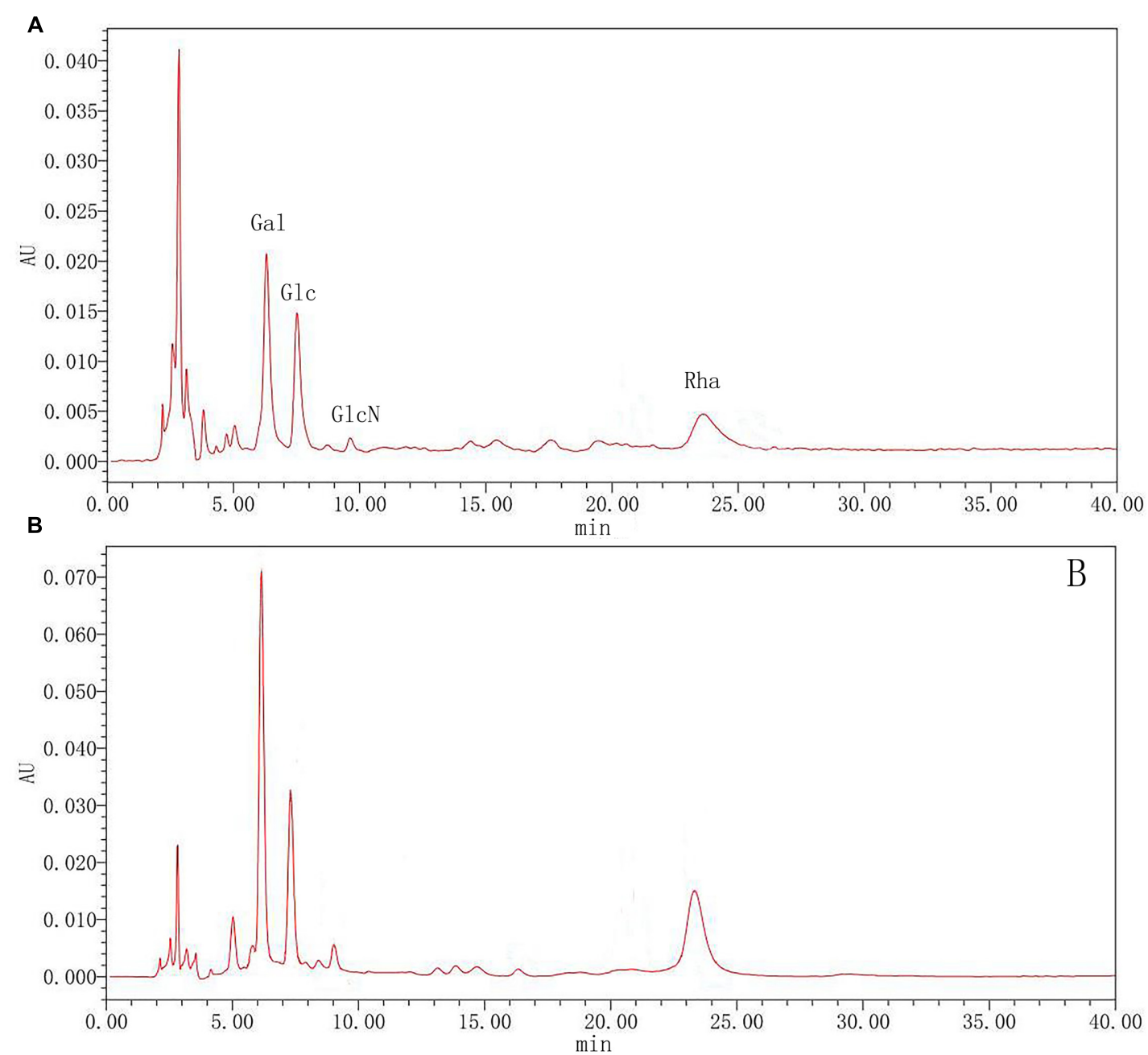

FIGURE 7 | High performance liquid chromatography (HPLC) chromatograms of monosaccharides after hydrolysis of polysaccharide in control (A) and rutin (B) groups.
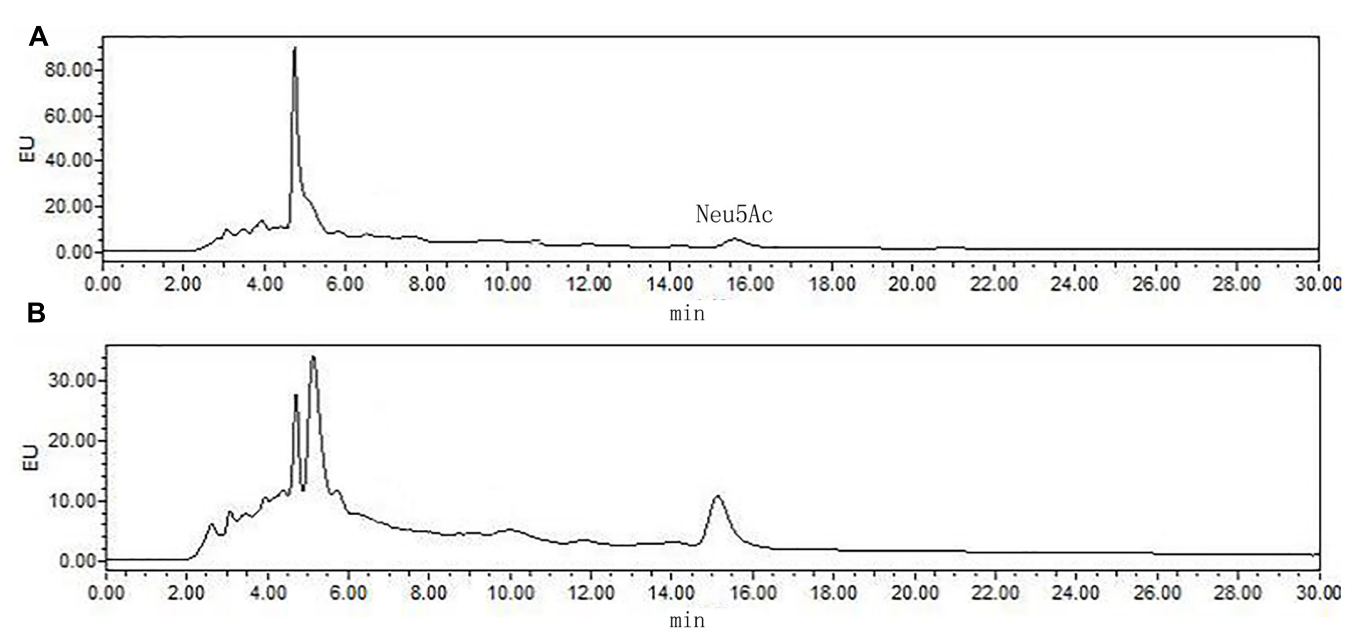

FIGURE 8 | High performance liquid chromatography chromatograms of sialic acid (Neu5Ac) in control (A) and rutin (B) groups. 


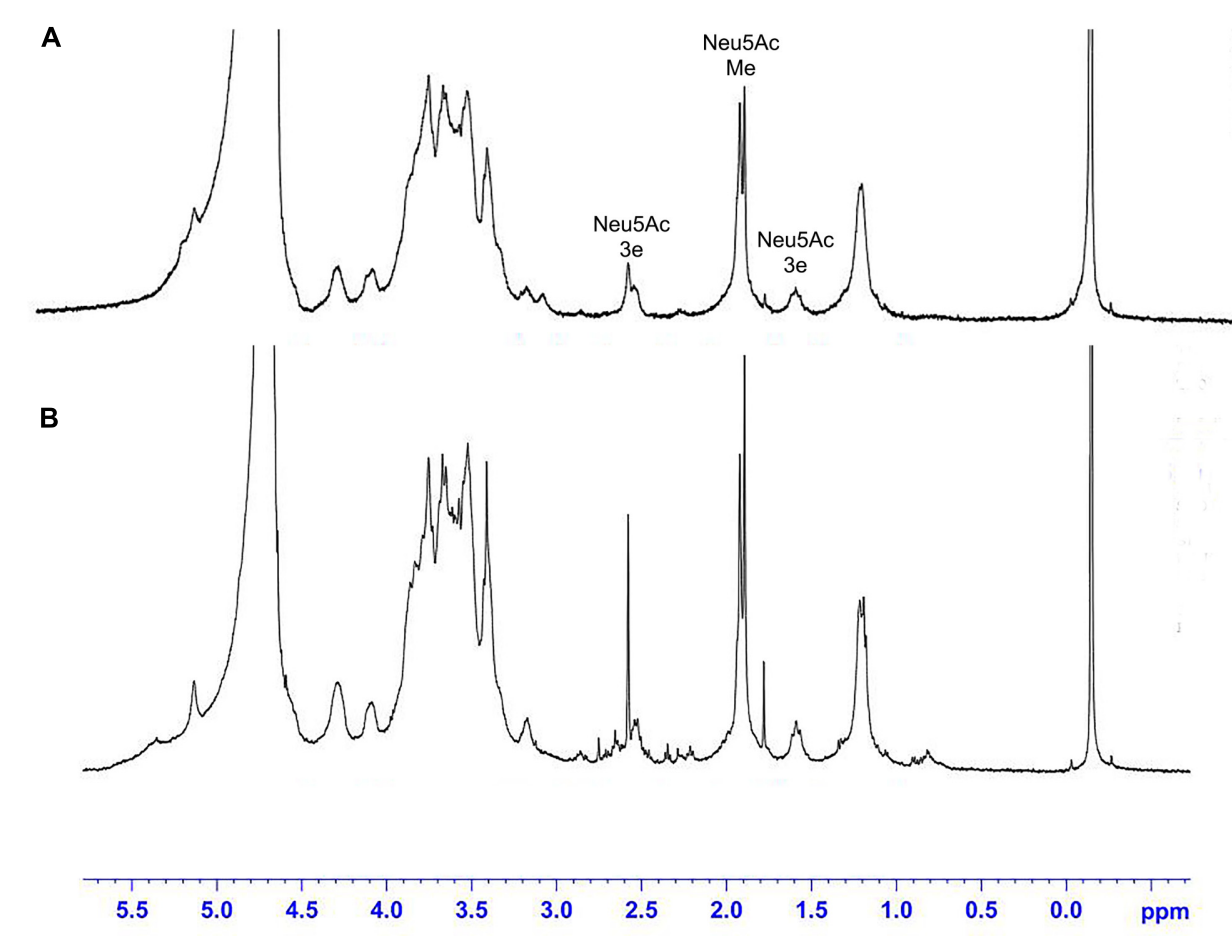

FIGURE 9 | $500 \mathrm{MHz}{ }^{1} \mathrm{H}$ nuclear magnetic resonance (NMR) spectra of capsular polysaccharide in control (A) and rutin (B) groups.

\section{DISCUSSION}

In this work the ability of rutin to inhabit S. suis biofilms was investigated by TCP assay and SEM. The TCP assay according to the ability of bacteria to form biofilms on the microplates indicated indirectly that the sub-inhibitory concentrations of rutin could inhibit the $S$. suis biofilm formation in vitro. Then, the effect of rutin on the structure of biofilm of S. suis was observed directly by SEM. Our results showed that rutin could inhibit S. suis biofilm formation at $1 / 4 \mathrm{MIC}(0.0781 \mathrm{mg} / \mathrm{mL})$. However, it is still unclear why rutin affects $S$. suis biofilms in vitro. In addition, a question remained unanswered: how does rutin affect S. suis biofilms at the molecular level? Then, we investigated the influence of rutin on $S$. suis growth in vitro. The results suggested that rutin could significantly inhibit biofilm formation of $S$. suis but had had no effect on its growth by the addition of 1/4MIC $(0.0781 \mathrm{mg} / \mathrm{mL})$ rutin. Rutin was previously shown to affect attachment of Staphylococcal aureus (Liu et al., 2015) and inhibit the Pseudomonas aeruginosa biofilm formation (Lou et al., 2015). Thus, anti-adherence activity of rutin was investigated. Our results showed that rutin inhibited adherence in an obvious manner.

Previous reports had demonstrated that CPS was play an important role in the adhesion of host cells (Allegrucci and Sauer, 2007), and the encapsulated clinical pneumococcal isolates have impaired biofilm formation (Moscoso et al., 2006). The structure of the CPS can also affect biofilm formation. For example, the $\alpha$-D-Glc is partially replaced with $\alpha$-D-GlcNAc in Vibrio cholera polysaccharide which gives it high viscosity and promotes biofilm formation (Yildiz et al., 2014). Thus, the content and structure of $S$. suis CPS were detected. Results showed that rutin are beneficial to improve the CPS content of S. suis. Elliott and Tai (Elliott and Tai, 1978) defined the capsular polysaccharide of S. suis as consisting of five sugars including Rha, Glc, Gal, GlcNAc and Neu5Ac. The polysaccharides in the rutin and control group contained five monosaccharides as above after hydrolysis and derivation. It is consistent with the results of Elliott and Tai (1978). Van Calsteren has given the description about the sugar structure of S. suis CPS (Van Calsteren et al., 2010). In this study, the same ${ }^{1} \mathrm{H}$ NMR spectra was observed in S. suis CPS when $S$. suis was cultivated in the presence of rutin. Our findings are in consistent with the results of Van Calsteren (Van Calsteren et al., 2010). According to our results, rutin had no effect on the structure of $S$. suis CPS. Therefore, rutin may affect the capsular polysaccharide content and then affect the bacterial adhesion and biofilm formation.

Finally, we addressed the question that how rutin resulted in an increased content of $S$. suis capsular polysaccharide. It has been stated earlier that multiple genes involved in the synthesis of CPS. Smith et al. (1999) identified cps gene cluster which is essential for the synthesis of the repeating unit of CPS and found that CPS is comprised of Glc, Gal, GlcN, Rha, and Neu5Ac. Van Calsteren et al. (2010) elucidated CPS structure of S. suis and predicted the cps genes responsible for the synthesis of CPS repeating units. In addition, $S$. suis CPS were considered to be synthesized by the $w z x / w z y$-dependent pathway due to possession of $w z x$ and $w z y$ genes (Wang K. et al., 2011; Okura et al., 2013). The genes in $w z x / w z y$-dependent pathway comprise 


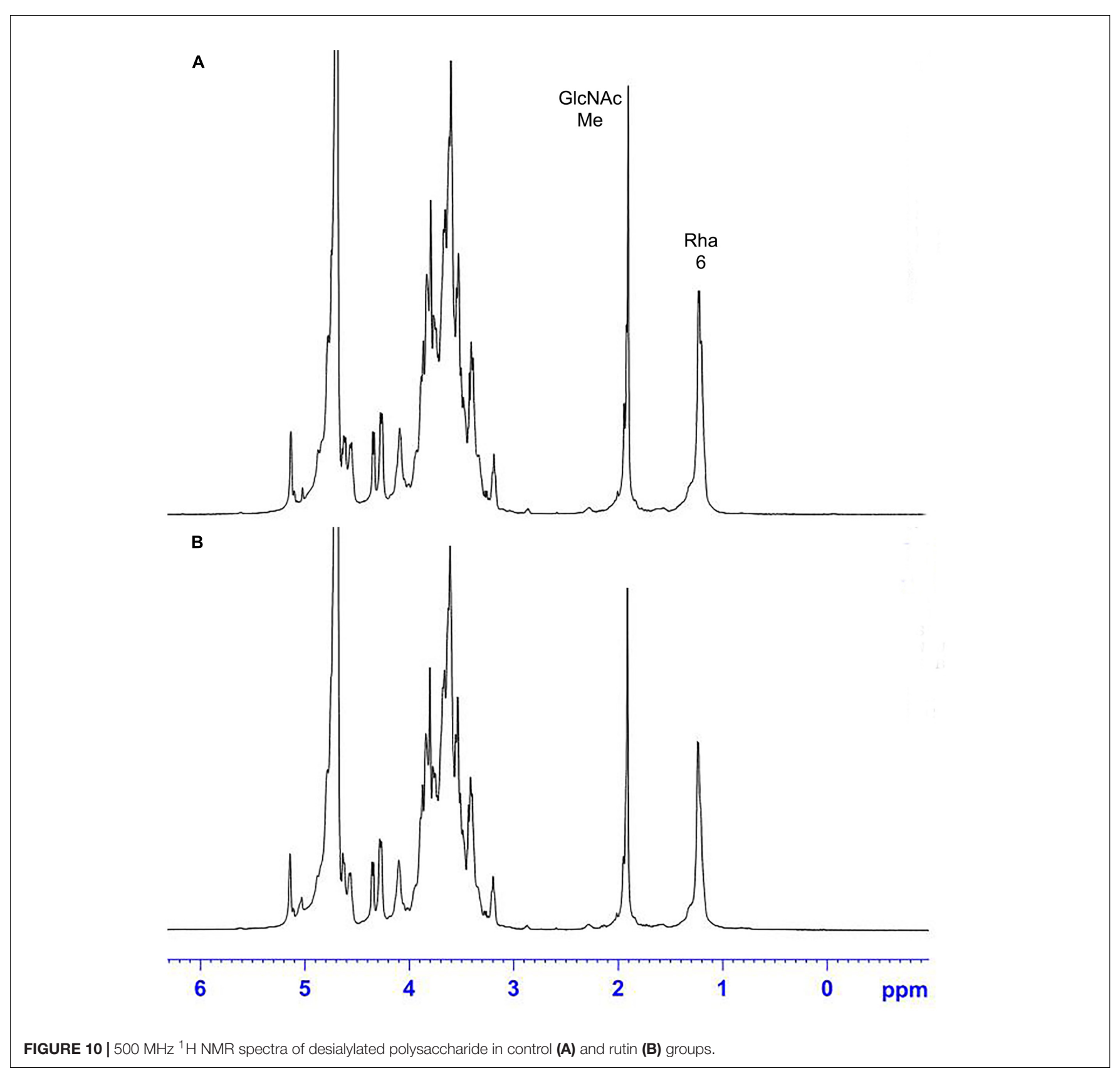

of cps gene cluster and are usually located at the same locus on chromosome (Bentley et al., 2006).

It has been predicted previously that cps $2 E$ gene was the initiating gene in the process of the synthesis of the repeating unit of CPS, and the removal of cps $2 E$ gene led to the complete absence of CPS, as was previously reported in Streptococcus pneumoniae (Cartee et al., 2005). In our study, we found that cps $2 E$ gene was significantly upregulated in the presence of rutin. The up regulation of cps $2 E$ may promote the synthesis of the capsular polysaccharide and thus inhibit biofilm formation. It has been demonstrated that the gene cps $2 L$ was responsible for the synthesis of sialyltrans-ferase which in turn mediate the transfer of sialic acid to CPS repeating units (Van Calsteren et al., 2010).
The sialic acid played a major role in the regulation of bacterial adhesion (Charland et al., 1996; Segura and Gottschalk, 2002; Lewis et al., 2012). The expression level of $c p s 2 L$ gene was up regulated in the present study. The up regulation of $c p s 2 L$ may promote the synthesis of the capsular polysaccharide.

Previously, it has been predicted that the gene cps $2 G$ and $c p s 2 J$ were involved in the synthesis of long side chain and short side chain of cps units (Van Calsteren et al., 2010). Although the expression level of cps $2 G$ gene did not change, the expression level of $c p s 2 J$ gene was up regulated in the present study. Furthermore, $c p s 2 L, c p s 2 E, c p s 2 J$, and $c p s 2 G$ gene were found in $S$. suis responsible for different glycosyltransferases involved in CPS synthesis. The above four deletion mutants with their sialic 
acid content decreased and CPS incomplete in S. suis SC19 and indicated enhanced adhesion to host cells (Zhang et al., 2016). Therefore, the up regulation of $c p s 2 J$ may promote the synthesis of the capsular polysaccharide.

It has been demonstrated that $\mathrm{CpsD}$ is an autophosphorylating tyrosine kinase regulated by $\mathrm{CpsC}$ that is required for $\mathrm{CpsD}$ tyrosine phosphorylation (Morona et al., 2000; Bender and Yother, 2001) and both may be important regulators connecting capsule synthesis to cell division. CpsB is a manganese dependent tyrosine phosphatase that influences dephosphorylation of $\mathrm{CpsD}$, as a kinase inhibitor, autophosphorylation of $\mathrm{CpsB}$ may prevent CpsD in its C-terminal tyrosine and weaken the activity of the CpsD protein, and inhibit the production of capsular polysaccharide. It has been mentioned earlier that a cps $2 D$ deleted strain produced lesser amount of CPS was avirulent (Morona et al., 2004). Much higher expressions were detected for cps2C and cps $2 D$ when $S$. suis was cultivated in the presence of rutin. The expression level of $c p s 2 A$ and $c p s 2 B$ gene was down regulated in the present study. $c p s B, c p s C$, and $c p s D$ are essential for encapsulation, while $c p s A$ is not necessary as previously reported (Morona et al., 2004). So, the expression level of cps $2 A$ gene down regulated may have no effect on the amount of capsular polysaccharide. These data suggested that the $c p s 2 B$, cps $2 C$, and cps $2 D$ expression might be partly responsible for the reduced biofilm. However, the detailed molecular mechanism still unknown.

\section{CONCLUSION}

Our findings demonstrate that $1 / 4 \mathrm{MIC}(0.0781 \mathrm{mg} / \mathrm{mL})$ of rutin inhibits $S$. suis biofilm formation without impairing its growth in vitro. We investigate the effect of rutin on S. suis CPS content and structure. The results reveal that rutin is beneficial to improve

\section{REFERENCES}

Allegrucci, M., and Sauer, K. (2007). Characterization of colony morphology variants isolated from Streptococcus pneumoniae biofilms. J. Bacteriol. 189, 2030-2038. doi: 10.1128/JB.01369-06

Bai, J., Yang, Y., Wang, S., Gao, L., Chen, J., Ren, Y., et al. (2017). Syringa oblata Lindl. Aqueous extract is a potential biofilm inhibitor in S. suis. Front. Pharmacol. 8:26. doi: 10.3389/fphar.2017.00026

Bender, M. H., and Yother, J. (2001). CpsB is a modulator of capsule-associated tyrosine kinase activity in Streptococcus pneumoniae. J. Biol. Chem. 276, 4796647974. doi: 10.1074/jbc.M105448200

Bentley, S. D., Aanensen, D. M., Mavroidi, A., Saunders, D., Rabbinowitsch, E., Collins, M., et al. (2006). Genetic analysis of the capsular biosynthetic locus from all 90 pneumococcal serotypes. PLoS Genet. 2:e31. doi: 10.1371/journal. pgen.0020031

Cartee, R. T., Forsee, W. T., Bender, M. H., Ambrose, K. D., and Yother, J. (2005). CpsE from type 2 Streptococcus pneumoniae catalyzes the reversible addition of glucose-1-phosphate to a polyprenyl phosphate acceptor, initiating type 2 capsule repeat unit formation. J. Bacteriol. 187, 7425-7433. doi: 10.1128/JB.187. 21.7425-7433.2005

Charland, N., Kobisch, M., Martineau-Doize, B., Jacques, M., and Gottschalk, M. (1996). Role of capsular sialic acid in virulence and resistance to phagocytosis of Streptococcus suis capsular type 2. FEMS Immunol. Med. Microbiol. 14, 195-203. doi: 10.1111/j.1574-695X.1996.tb00287.x the polysaccharide content of $S$. suis without changing its structure. The potential mechanism may be that rutin is beneficial to improve the polysaccharide content of $S$. suis which affects bacterial adhesion. The $c p s 2 B, c p s 2 C, c p s 2 D, c p s 2 E, c p s 2 J$, and $c p s 2 L$ might be responsible for the reduced biofilm. Altogether our findings demonstrate that rutin interfers with CPS synthesis in S. suis and thereby decreases biofilm formation of S. suis. Thus, our findings found the rough regulation of $S$. suis biofilm formation that may be utilized potentially to manage S. suis biofilm infections.

\section{AUTHOR CONTRIBUTIONS}

Conceived and designed the experiments: YL. Performed the experiments: SW, CW, LG, YZ, YY, CX. Analyzed the data: WD, JC, IM, XC. Contributed reagents/materials/analysis tools: HC, $\mathrm{XH}, \mathrm{DL}$.

\section{ACKNOWLEDGMENTS}

This work was supported by the National Natural Science Foundation of China (No. 31472231), National Science and Technology Support Plan of China (No. 2015BAD11B00), and Ministry of agriculture pig industry system (CARS-36).

\section{SUPPLEMENTARY MATERIAL}

The Supplementary Material for this article can be found online at: http://journal.frontiersin.org/article/10.3389/fphar. 2017.00379/full\#supplementary-material

FIGURE S1-S21 | Effect of rutin on cps gene sequences.

Conlon, B. P. (2014). Staphylococcus aureus chronic and relapsing infections: evidence of a role for persister cells: an investigation of persister cells, their formation and their role in S. aureus disease. Bioessays 36, 991-996. doi: 10. 1002/bies.201400080

Dubois, M., Gilles, K., Hamilton, J. K., Rebers, P. A., and Smith, F. (1951). A colorimetric method for the determination of sugars. Nature 168, 167. doi: $10.1038 / 168167 \mathrm{a} 0$

Elliott, S. D., and Tai, J. Y. (1978). The type-specific polysaccharides of Streptococcus suis. J. Exp. Med. 148, 1699-1704. doi: 10.1084/jem.148.6.1699

Erlund, I., Kosonen, T., Alfthan, G., Maenpaa, J., Perttunen, K., Kenraali, J., et al. (2000). Pharmacokinetics of quercetin from quercetin aglycone and rutin in healthy volunteers. Eur. J. Clin. Pharmacol. 56, 545-553. doi: 10.1007/ s002280000197

Fux, C. A., Costerton, J. W., Stewart, P. S., and Stoodley, P. (2005). Survival strategies of infectious biofilms. Trends Microbiol. 13, 34-40. doi: 10.1016/j.tim. 2004.11.010

Gilbert, P., Das, J., and Foley, I. (1997). Biofilm susceptibility to antimicrobials. Adv. Dent. Res. 11, 160-167.

Gottschalk, M., Segura, M., and Xu, J. (2007). Streptococcus suis infections in humans: the Chinese experience and the situation in North America. Anim. Health Res. Rev. 8, 29-45. doi: 10.1017/S1466252307001247

Gottschalk, M., Xu, J., Calzas, C., and Segura, M. (2010). Streptococcus suis: a new emerging or an old neglected zoonotic pathogen? Future Microbiol. 5, 371-391. doi: $10.2217 / \mathrm{fmb} .10 .2$ 
Guitang, H. A. O., Shangwei, C., Song, Z. H. U., Hongping, Y. I. N., Jun, D. A. I., and Yuhua, C. A. O. (2007). Analysis of monosaccharides and uronic acids in polysaccharides by pre-column derivatization with $\mathrm{p}$-aminobenzoic acid and high performance liquid chromatography. Chin. J. Chromatogr. 25, 75-79.

Hamada, S., Torii, M., Kotani, S., and Tsuchitani, Y. (1981). Adherence of Streptococcus sanguis clinical isolates to smooth surfaces and interactions of the isolates with Streptococcus mutans glucosyltransferase. Infect. Immun. 32, 364-372.

Islam, B., Khan, S. N., Haque, I., Alam, M., Mushfiq, M., and Khan, A. U. (2008). Novel anti-adherence activity of mulberry leaves: inhibition of Streptococcus mutans biofilm by 1-deoxynojirimycin isolated from Morus alba. J. Antimicrob. Chemother. 62, 751-757. doi: 10.1093/jac/dkn253

Katsumi, M., Saito, T., Kataoka, Y., Itoh, T., Kikuchi, N., and Hiramune, T. (1996). Comparative preparation methods of sialylated capsule antigen from Streptococcus suis type 2 with type specific antigenicity. J. Vet. Med. Sci. 58, 947-952.

Kiedrowski, M. R., and Horswill, A. R. (2011). "New approaches for treating staphylococcal biofilm infections," in Antimicrobial Therapeutics Reviews: Antibiotics That Target the Ribosome, ed. K. Bush (Hoboken, NJ: WileyBlackwell), 104-121.

Koo, H., and Jeon, J. G. (2009). Naturally occurring molecules as alternative therapeutic agents against cariogenic biofilms. Adv. Dent. Res. 21, 63-68. doi: 10.1177/0895937409335629

Lewis, L. A., Carter, M., and Ram, S. (2012). The relative roles of factor H binding protein, neisserial surface protein $\mathrm{A}$, and lipooligosaccharide sialylation in regulation of the alternative pathway of complement on meningococci. J. Immunol. 188, 5063-5072. doi: 10.4049/jimmunol.1103748

Liu, B., Chen, F., Bi, C., Wang, L., Zhong, X., Cai, H., et al. (2015). Quercitrin, an inhibitor of Sortase A, interferes with the adhesion of Staphylococcal aureus. Molecules 20, 6533-6543. doi: 10.3390/molecules20046533

Lou, Z., Tang, Y., Song, X., and Wang, H. (2015). Metabolomics-based screening of biofilm-inhibitory compounds against Pseudomonas aeruginosa from burdock leaf. Molecules 20, 16266-16277. doi: 10.3390/molecules200916266

McDougald, D., Rice, S. A., Barraud, N., Steinberg, P. D., and Kjelleberg, S. (2012). Should we stay or should we go: mechanisms and ecological consequences for biofilm dispersal. Nat. Rev. Microbiol. 10, 39-50. doi: 10.1038/nrmicro2695

McEllistrem, M. C., Ransford, J. V., and Khan, S. A. (2007). Characterization of in vitro biofilm-associated pneumococcal phase variants of a clinically relevant serotype 3 clone. J. Clin. Microbiol. 45, 97-101. doi: 10.1128/JCM.01658-06

Middleton, E. Jr., Kandaswami, C., and Theoharides, T. C. (2000). The effects of plant flavonoids on mammalian cells: implications for inflammation, heart disease, and cancer. Pharmacol. Rev. 52, 673-751.

Morona, J. K., Miller, D. C., Morona, R., and Paton, J. C. (2004). The effect that mutations in the conserved capsular polysaccharide biosynthesis genes cpsA, cpsB, and cpsD have on virulence of Streptococcus pneumoniae. J. Infect. Dis. 189, 1905-1913. doi: 10.1086/383352

Morona, J. K., Paton, J. C., Miller, D. C., and Morona, R. (2000). Tyrosine phosphorylation of CpsD negatively regulates capsular polysaccharide biosynthesis in streptococcus pneumoniae. Mol. Microbiol. 35, 1431-1442. doi: 10.1046/j.1365-2958.2000.01808.x

Moscoso, M., Garcia, E., and Lopez, R. (2006). Biofilm formation by Streptococcus pneumoniae: role of choline, extracellular DNA, and capsular polysaccharide in microbial accretion. J. Bacteriol. 188, 7785-7795. doi: 10.1128/JB.00673-06

Okura, M., Takamatsu, D., Maruyama, F., Nozawa, T., Nakagawa, I., Osaki, M., et al. (2013). Genetic analysis of capsular polysaccharide synthesis gene clusters from all serotypes of Streptococcus suis: potential mechanisms for generation of capsular variation. Appl. Environ. Microbiol. 79, 2796-2806. doi: 10.1128/AEM. 03742-12

Qin, L., Watanabe, H., Yoshimine, H., Guio, H., Watanabe, K., Kawakami, K., et al. (2006). Antimicrobial susceptibility and serotype distribution of Streptococcus pneumoniae isolated from patients with community-acquired pneumonia and molecular analysis of multidrug-resistant serotype $19 \mathrm{~F}$ and $23 \mathrm{~F}$ strains in Japan. Epidemiol. Infect. 134, 1188-1194. doi: 10.1017/S09502688060 06303

Roberts, I. S. (1996). The biochemistry and genetics of capsular polysaccharide production in bacteria. Annu. Rev. Microbiol. 50, 285-315. doi: 10.1146/ annurev.micro.50.1.285

Roca, I., Akova, M., Baquero, F., Carlet, J., Cavaleri, M., Coenen, S., et al. (2015). The global threat of antimicrobial resistance: science for intervention. New Microbes New Infect. 6, 22-29. doi: 10.1016/j.nmni.2015.02.007

Segura, M., and Gottschalk, M. (2002). Streptococcus suis interactions with the murine macrophage cell line J774: adhesion and cytotoxicity. Infect. Immun. 70, 4312-4322. doi: 10.1128/IAI.70.8.4312-4322.2002

Smith, H. E., Damman, M., Van Der Velde, J., Wagenaar, F., Wisselink, H. J., Stockhofe-Zurwieden, N., et al. (1999). Identification and characterization of the cps locus of Streptococcus suis serotype 2: the capsule protects against phagocytosis and is an important virulence factor. Infect. Immun. 67, 17501756.

Sriskandan, S., and Slater, J. D. (2006). Invasive disease and toxic shock due to zoonotic Streptococcus suis: an emerging infection in the East? PLoS Med. 3:e187. doi: 10.1371/journal.pmed.0030187

Van Calsteren, M.-R., Gagnon, F., Lacouture, S., Fittipaldi, N., and Gottschalk, M. (2010). Structure determination of Streptococcus suis serotype 2 capsular polysaccharide. Biochem. Cell Biol. 88, 513-525. doi: 10.1139/o09-170

Waite, R. D., Struthers, J. K., and Dowson, C. G. (2001). Spontaneous sequence duplication within an open reading frame of the pneumococcal type 3 capsule locus causes high-frequency phase variation. Mol. Microbiol. 42, 1223-1232. doi: 10.1046/j.1365-2958.2001.02674.x

Wang, K., Fan, W. X., Cai, L. J., Huang, B. X., and Lu, C. P. (2011). Genetic analysis of the capsular polysaccharide synthesis locus in 15 Streptococcus suis serotypes. FEMS Microbiol. Lett. 324, 117-124. doi: 10.1111/j.1574-6968.2011.02394.x

Wang, Y., Zhang, W., Wu, Z., and Lu, C. (2011). Reduced virulence is an important characteristic of biofilm infection of Streptococcus suis. FEMS Microbiol. Lett. 316, 36-43. doi: 10.1111/j.1574-6968.2010.02189.x

Yang, W.-Z., Yu, H.-J., Jing, H.-Q., Xu, J.-G., Chen, Z.-H., Zhu, X.-P., et al. (2006). An outbreak of human Streptococcus suis serotype 2 infections presenting with toxic shock syndrome in Sichuan, China. Zhonghua liu xing bing xue za zhi27, $185-191$.

Yang, Y. B., Wang, S., Wang, C., Huang, Q. Y., Bai, J. W., Chen, J. Q., et al. (2015). Emodin affects biofilm formation and expression of virulence factors in Streptococcus suis ATCC700794. Arch. Microbiol. 197, 1173-1180. doi: 10.1007/ s00203-015-1158-4

Yildiz, F., Fong, J., Sadovskaya, I., Grard, T., and Vinogradov, E. (2014). Structural characterization of the extracellular polysaccharide from Vibrio cholerae $\mathrm{O} 1$ El-Tor. PLoS ONE 9:e86751. doi: 10.1371/journal.pone.0086751

Zhang, Y., Ding, D., Liu, M., Yang, X., Zong, B., Wang, X., et al. (2016). Effect of the glycosyltransferases on the capsular polysaccharide synthesis of Streptococcus suis serotype 2. Microbiol. Res. 185, 45-54. doi: 10.1016/j.micres.2016.02.002

Conflict of Interest Statement: The authors declare that the research was conducted in the absence of any commercial or financial relationships that could be construed as a potential conflict of interest.

Copyright (c) 2017 Wang, Wang, Gao, Cai, Zhou, Yang, Xu, Ding, Chen, Muhammad, Chen, $\mathrm{He}$, Liu and Li. This is an open-access article distributed under the terms of the Creative Commons Attribution License (CC BY). The use, distribution or reproduction in other forums is permitted, provided the original author(s) or licensor are credited and that the original publication in this journal is cited, in accordance with accepted academic practice. No use, distribution or reproduction is permitted which does not comply with these terms. 